\title{
Advances in PCR-based Detection of Mycoplasmas Contaminating Cell Cultures
}

\author{
Georges Rawadi and Olivier Dussurget
}

Laboratoire des Mycoplasmes, Département de Bactériologie et Mycologie, Institut Pasteur, 75724 Paris, CEDEX 15, France

ycoplasmas (the trivial name for microorganisms belonging to the class Mollicutes) are the smallest free-living, self-replicating bacteria, having diameters of 300 to $800 \mathrm{~nm}$. These pleomorph microorganisms have no cell walls. ${ }^{(1)} \mathrm{Be}$ cause of their small size and flexibility, mollicutes can pass through filters of 450 and $220 \mathrm{~nm}$ used commonly in cell culturing. ${ }^{(1,2)}$

Mollicute contamination of primary and continuous eukaryotic cell lines represents a major problem of economic and biological importance in basic research, diagnosis, and biotechnological production. This contamination problem is widespread. Surveys show that $5-87 \%$ of cell lines are contaminated. $^{(3-6)}$ There are currently $>120$ mollicute species, ${ }^{(1)}$ but 5 species account for $>95 \%$ of cell contaminations. ${ }^{(3,7-9)}$ The common contaminants are two bovine mollicutes, Mycoplasma arginini and Acholeplasma laidlawii; two human mollicutes, Mycoplasma orale and Mycoplasma fermentans; and a porcine mollicute, Mycoplasma hyorhinis. ${ }^{(10)}$ Figure 1 shows a fibroblastic cell line contaminated with $M$. fermentans detected by scanning electron microscopy.

Although contamination originates from laboratory personnel and commercial animal sera used in culture media, the main source of contamination of clean cultures is mollicute-infected cultures. $(2,7,11)$

Mollicutes are capable of altering virtually every property and parameter measured in cell cultures, depending on the contaminating species and on the type of cell infected, leading to unreliable experiments and unsafe biologicals, biopharmaceutical drugs, and virus vaccines. It has been shown that mollicutes affect cell growth and morphology, nu-

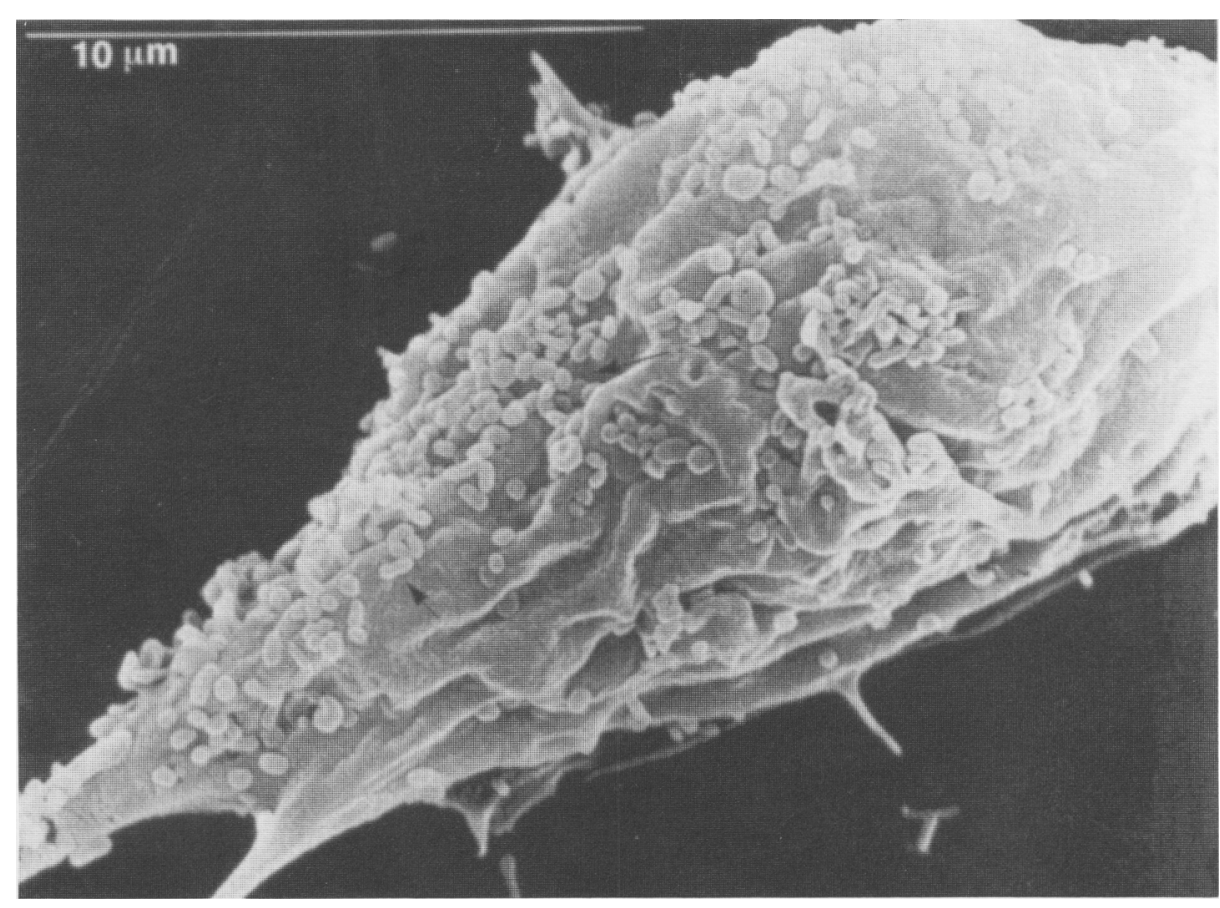

FIGURE 1 Scanning electron microscopy of 3T6 cell line infected with M. fermentans. Arrows indicate the mycoplasmas adsorbed on the cell surface.

cleic acid and amino acid metabolism, and production of virus and biologic products, such as cytokines and monoclonal antibodies. ${ }^{(3,7,9,12,13)}$ Unlike bacteria and fungi, mollicute contaminants usually produce neither turbid growth nor cell damage. ${ }^{(6)}$ Moreover, most mollicutes are resistant to antibiotics commonly used in long-term cell cultures. ${ }^{(6,12)}$ Periodic screening is therefore essential in controlling contamination and maintaining mollicute-free cell lines.

Numerous methods for detecting mollicute infection have been developed. Direct tests are based on microbiological culture, and indirect tests are based on measurement of specific mark- ers or characteristics associated with mollicutes, including DNA fluorochrome staining, DNA probes, enzymelinked immunosorbent assay (ELISA), immunofluorescence, electron microscopy, autoradiography, and biochemical assays. ${ }^{(2,6,10,13)}$ Although efforts have focused on the improvement of these techniques, detection of mollicutes in cell cultures remains a serious problem. Recently, the application of PCR-based methods of detection has attracted much attention because of their extreme sensitivity and specificity. Because the pace of PCR technology advancement is so rapid, detection methods have evolved quickly. The objective of this review is to present the latest develop- 
ments in the field of PCR-based detection of mollicutes contaminating cell cultures. PCR-based methods are described and compared with other mollicute detection assays.

\section{GENERAL PRINCIPLES OF PCR DETECTION}

The PCR technique is based on repeated cycles of high-temperature template denaturation, oligonucleotide primer annealing, and thermostable polymerasemediated extension. ${ }^{(14)}$ The number of DNA molecules doubles after each cycle, somewhat mimicking in vivo DNA replication. Because PCR allows the specific amplification of discrete fragments of mollicute DNA and can generate millions of DNA copies from the template sequence, it makes the detection of mollicutes easier, even in cell cultures with low contamination.

\section{Characteristics of Target Nucleic Acids and Primers}

Virtually all forms of double-stranded nucleic acids are suitable substrates for PCR. Mycoplasmic 16S rRNA sequences have been determined and provide the basis for a systematic phylogenetic analysis of mollicutes. ${ }^{(15)}$ Typically, PCR targets are chosen within the gene coding for this evolutionarily conserved $16 \mathrm{~S}$ rRNA (Tables 1 and 2). ${ }^{(16-22)}$ Computer alignment studies of mollicute $16 \mathrm{~S}$ rRNA sequences have revealed the existence of regions with highly conserved sequences and regions with sequence variability at the genus and species levels, allowing the selection of genus- and species-specific primers and, thus, detection and identification of mollicutes. However, most investigators have reported the relative specificity of their primers, especially when used in one-step PCR procedures. Some workers observed cross-reactions with walled prokaryotes in genus-specific conditions (Table $1),{ }^{(20,21)}$ or cross-reactions between mollicutes in species-specific PCR conditions. ${ }^{(19,27)}$ Others used primers that did not cross-react with bacteria that is

TABLE 1 Primers used in Detection by PCR of Mycoplasma-contaminated Cell Cultures

\begin{tabular}{|c|c|c|c|c|c|}
\hline $\begin{array}{l}\text { Primer } \\
\text { designation }^{a}\end{array}$ & Sequence $5^{\prime} \rightarrow 3^{\prime}$ & $\begin{array}{l}\text { Site on } 16 \mathrm{~S} \\
\text { or } 23 \mathrm{~S} \text { rRNA }\end{array}$ & $\begin{array}{l}\text { Undetected } \\
\text { species }\end{array}$ & Cross-reaction & Reference \\
\hline 1-P1 & GTGCCAGCAGCCGCGGTAATAC & $\mathrm{NR}^{\mathrm{b}}$ & none & prokaryotes & 20 \\
\hline 2-P2 & TCTACGCATTTCACCGCTACAC & $\mathrm{NR}^{\mathrm{b}}$ & & & 20 \\
\hline 1-P3 & CTTGTACACACCGCCCGTCACACCATG & $\mathrm{NR}^{\mathrm{b}}$ & none & prokaryotes & 20 \\
\hline 2-P4 & TACCTTGTTACGACTTCACCCCA & $N^{b}$ & & & 20 \\
\hline $1-\mathrm{P} 3$ & CTTGTACACACCGCCCGTCACACCATG & $\mathrm{NR}^{\mathrm{b}}$ & M. orale & none & 20 \\
\hline 2-IP3 & ATCGCTAGTCCTACCTTGGG & $\mathrm{NR}^{\mathrm{b}}$ & A. laidlawii & & 20 \\
\hline 1-P3 & CTTGTACACACCGCCCGTCACACCATG & $\mathrm{NR}^{\mathrm{b}}$ & A. laidlawii & none & 20 \\
\hline $2-\mathrm{IP}^{\prime} 3$ & GTCACCAGTCCTACCTTAGG & $\mathrm{NR}^{\mathrm{b}}$ & & & 20 \\
\hline 1-MCGpF11 ${ }^{\mathrm{c}}$ & ACACCAAGGGAG(C/T)TGGTAAT & $\mathrm{NR}^{\mathrm{b}}$ & none & NR & 23 \\
\hline $2-\mathrm{R} 23-1 \mathrm{R}^{\mathrm{C}}$ & CTCCTAGTGCCAAG(C/G)CAT(C/T)C & $\mathrm{NR}^{\mathrm{d}}$ & & & 23 \\
\hline $3-\mathrm{R} 16-2^{\mathrm{C}}$ & GTG(C/G)GG(A/C)TGGATCACCTCCT & $\mathrm{NR}^{\mathrm{b}}$ & none & NR & 23 \\
\hline 4-MCGpR21 & GCATCCACCA(A/T)A(A/T)AC(C/T)CTT & $\mathrm{NR}^{\mathrm{d}}$ & & & 23 \\
\hline $1-\mathrm{F} 1^{\mathrm{c}}$ & ACACCATGGGAG(C/T)TGGTAAT & $\mathrm{NR}^{\mathrm{b}}$ & none & NR & 24 \\
\hline $2-R 1^{c}$ & CTTC(A/T)TCGACTT(C/T)CAGACCCAAGGCAT & $\mathrm{NR}^{\mathrm{d}}$ & & & 24 \\
\hline $3-F 2^{\mathrm{C}}$ & GTG(C/G)GG(A/C)TGGATCACCTCCT & $N^{b}$ & none & NR & 24 \\
\hline $4-\mathrm{R}^{\mathrm{c}}$ & GCATCCACCA(A/T)A(A/T)AC(C/T)CTT & $\mathrm{NR}^{\mathrm{d}}$ & & & 16 \\
\hline $1-$ Myco $9^{c}$ & $(\mathrm{C} / \mathrm{T}) \mathrm{GCCTG}(\mathrm{A} / \mathrm{G}) \mathrm{GTAGTA}(\mathrm{C} / \mathrm{T})(\mathrm{A} / \mathrm{G})(\mathrm{T} / \mathrm{C})(\mathrm{T} / \mathrm{A}) \mathrm{CGC}$ & $N^{b}$ & none & NR & 16 \\
\hline 2 -Myco $3^{\mathrm{c}}$ & GCGGTGTGTACAA(G/A)(A/C)CCCGA & & & & 16 \\
\hline 3-Myco $8^{\mathrm{c}}$ & TGGTGCA(T/C)GGTTGTCGTCAG & $\mathrm{NR}^{\mathrm{b}}$ & none & NR & 16 \\
\hline $4-\mathrm{Myco} 5^{\mathrm{c}}$ & GAACGTATTCACCG $(\mathrm{C} / \mathrm{T})(\mathrm{A} / \mathrm{G})(\mathrm{G} / \mathrm{A})(\mathrm{C} / \mathrm{T})(\mathrm{A} / \mathrm{G}) \mathrm{T}(\mathrm{A} / \mathrm{G})$ & $N^{b}$ & & & 16 \\
\hline $1-$-My 1 & GCTGTGTGCCTAATACATGCAT & $41-62^{\mathrm{b}, \mathrm{e}}$ & none & none & 18 \\
\hline 2-My 2 & TGGTAGACAGTGAGACAATTGGAG & $1013-1036^{\mathrm{b}, \mathrm{e}}$ & & & 18 \\
\hline 1-Molli 1 & TACGGGAGGCAGCAGTA & $343-359^{\mathrm{b}, \mathrm{f}}$ & A. laidlawii & Clostridia & 21 \\
\hline 2-Molli 2a & TCAAGATAAAGTCATTTCCT & $463-482^{b, f}$ & & & 21 \\
\hline 1-Molli 1 & TACGGGAGGCAGCAGTA & $343-359^{b, f}$ & $\begin{array}{l}\text { Mycoplasma } \\
\text { species }\end{array}$ & none & 21 \\
\hline 2-Molli 2b & TACCGTCAATTTTTAATTTTT & $451-471^{\mathrm{b}, \mathrm{f}}$ & none & & 21 \\
\hline 1-RNA5 & AGAGTTTGATCCTGGCTCAGGA & $10-31^{\mathrm{f}}$ & & $\begin{array}{c}\text { Gram-positive } \\
\text { bacteria }^{2}\end{array}$ & 19 \\
\hline 2-RNA3 & ACGAGCTGACGACAACCATGCAC & $1068-1043^{f}$ & none & & 19 \\
\hline $1-G P O-3$ & GGGAGCAAACAGGATTAGATACCCT & $774-798^{f}$ & prokaryotes & NR & 25 \\
\hline 2-MGSO & TGCACCATCTGTCACTCTGTTAACCTC & $1029-1055^{f}$ & & & 25 \\
\hline
\end{tabular}

a(1-/2-) Primer pairs for one-step PCR or outer primers for nested PCR; (3-/4-) inner primers for nested PCR.

${ }^{b} 16 S$ rRNA gene.

'Parentheses indicate nucleotide degeneration. (NR) Not reported.

d23S rRNA gene.

eUsing M. fermentans $16 \mathrm{~S}$ rDNA as a reference.

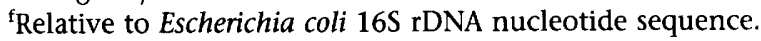

${ }^{\mathrm{L}}$ Low G $+\mathrm{C}$ Gram-positive bacteria. 
TABLE 2 Species-specific Primers for Identification by PCR of Mycoplasma-contaminated Cell Culture

\begin{tabular}{|c|c|c|c|c|}
\hline $\begin{array}{l}\text { Primer } \\
\text { designation }\end{array}$ & Sequence $5^{\prime} \rightarrow 3^{\prime}$ & $\begin{array}{c}\text { Site on } \\
16 S \text { rRNA }^{\mathrm{a}}\end{array}$ & $\begin{array}{c}\text { Species } \\
\text { specificity }\end{array}$ & Reference \\
\hline $\mathrm{ARG} 2^{\mathrm{b}}$ & TCAACCAGGTGTTCTTTCCC & $460-440$ & M. arginini & 19 \\
\hline $\mathrm{ACH}^{\mathrm{b}}$ & AGCCGGACTGAGGGTCTAC & $277-296$ & A. laidlawii & 19 \\
\hline $\mathrm{FER}^{\mathrm{b}}$ & AAGAAGCGTTTCTTCGCTGG & $203-222$ & M. fermentans & 19 \\
\hline $\mathrm{HYO}^{\mathrm{b}}$ & GAAAGGAGCTTCACAGCTTC & $198-217$ & M. hyorhinis & 19 \\
\hline ORA $^{\mathrm{b}}$ & GGAGCGTTTCGTCCGCTAAG & $199-218$ & M. orale & 19 \\
\hline PIR $^{\mathrm{b}}$ & GTCCGTTTGGACCGCTATAG & $203-222$ & M. pirum & 19 \\
\hline $\mathrm{SAL}^{\mathrm{b}}$ & GCTGCGTCAACAGTTCTCTG & $849-830$ & M. salivarium & 19 \\
\hline PNEU-GEN ${ }^{b}$ & CCTGCAAGGGTTCGTTATTT & $204-223$ & $\begin{array}{l}\text { M. pneumoniae/ } \\
\text { M. genitalium }\end{array}$ & 19 \\
\hline moli $2 b^{c}$ & TACCGTCAATTTTTAATTTT & $451-471$ & A. laidlawii & 21 \\
\hline$P 1^{\mathrm{c}}$ & AAGGACCTGCAAGGGTTCGT & NR & M. pneumoniae & 22 \\
\hline$P 2^{\mathrm{c}}$ & CTCTAGCCATTACCTGCTAA & NR & M. pneumoniae & 22 \\
\hline$P 1^{d}$ & TGAAAGGCGCTGTAAGGCGC & NR & M. hominis & 22 \\
\hline$P 2^{\mathrm{d}}$ & GTCTGCAATCATTTCCTATTGCAAA & NR & M. hominis & 22 \\
\hline $\mathrm{P} 1^{\mathrm{e}}$ & GAAGCCTTTCTTCGCTGGAG & NR & M. fermentans & 22 \\
\hline $\mathrm{P} 2^{\mathrm{e}}$ & ACAAAATCATTTCCTATTCTGTC & NR & M. fermentans & 22 \\
\hline$P 1^{\mathrm{f}}$ & AGCGTTTGCTTCACTTTGAA & NR & M. pulmonis & 22 \\
\hline$P 2^{f}$ & GGGCATTTCCTCCCTAAGCT & NR & M. pulmonis & 22 \\
\hline $\mathrm{RNA}^{\mathrm{b}}$ & TTCTATAGCTTTGCCAAG & NR & M. pirum & 26 \\
\hline Phyo $^{b}$ & TTCACAGCTTCACTTAAAA & $207-225$ & M. hyorhinis & 18 \\
\hline Pora $^{\mathrm{b}}$ & GCGTTTCGTCCGCTAAGA & $202-219$ & M. orale & 18 \\
\hline Pacho $^{\mathrm{b}}$ & AACACATTTAAAGATTTA & $189-206$ & A. laidlawii & 18 \\
\hline Psal $^{\text {b }}$ & GGGCCTTTAAAGCTCCAC & $200-217$ & M. salivarium & 18 \\
\hline Parg ${ }^{\mathrm{b}}$ & GCGAGGTTCTTTTGAACC & $68-85$ & M. arginini & 18 \\
\hline Pfer $^{b}$ & TTTCTTCGCTGGAGGAGCG & $206-224$ & M. fermentans & 18 \\
\hline
\end{tabular}

${ }^{\mathrm{a}} \mathrm{IUB}$ E. coli $16 \mathrm{~S}$ rRNA position.

${ }^{b}$ Used with a genus-specific primer to perform PCR.

${ }^{c-f}$ Primer pairs used together to perform PCR. (NR) Not reported.

closely related to mollicutes phylogenetically, but did not amplify all mollicute species, especially $A$. laidlawii (Table $1)^{(20,26)}$ The initial divergence of mollicutes from their clostridial ancestors has been shown to involve the Acholeplasma branch. ${ }^{(15)}$

A commercial mollicute detection method uses specific primers to detect heterogeneity within the mollicute tRNA gene cluster. ${ }^{(28)}$ Another original approach has been developed by Harasawa and co-workers. ${ }^{(23,29)}$ They showed that amplification of the 16S-23S spacer region in rRNA operons of mollicutes, using primers for the flanking $16 \mathrm{~S}$ and $23 \mathrm{~S}$ structural genes, is a highly specific approach leading to the identification of contaminant mollicutes, especially when followed by restriction analysis (Table 1). ${ }^{(24)}$

\section{Setting Up Amplification}

Sufficient sensitivity and specificity of PCR are prerequisites for its use in the diagnosis of mollicute infection of cell lines, for detecting small amounts of mollicute DNA among the eukaryotic gene material. Primer design is one of the most important factors affecting the quality of PCR. Primer selection criteria, like the adjustment of PCR conditions, such as temperature, duration of PCR steps, and composition of the reaction mixture, may improve the reaction sensitivity and specificity considerably. An alignment study of specific nucleotide sequences showing mollicute genus- and species-specific regions (see above) is a useful tool when selecting a primer pair and predicting its specificity properties. In contrast, a trial-and-error approach by new combinations of primers derived from slightly different positions of the original target gene sequences is necessary to improve the sensitivity properties of a primers pair, because so far there is no means of predicting such sensitivity. ${ }^{(30)}$

The efficacy of PCR is measured by its specificity, efficiency, and fidelity. The ideal PCR with high specificity, efficiency, and fidelity is difficult to set up because the conditions for maximizing these parameters are sometimes incom- patible. ${ }^{(31)}$ Several recent PCR-based methods of diagnosing cell culture infection by mollicutes detected both mollicutes and bacteria that are closely related phylogenetically to mollicutes. ${ }^{(19,21)}$ Nevertheless, when compared with more specific methods that fail to amplify several mollicute species, ${ }^{(26)}$ these recent methods seem more convenient for the purpose of detecting cell line contaminants. This is because the crossreacting bacteria, such as Clostridium innocuum and Clostridium ramosum, are never found as cell culture contaminants. Furthermore, in the field of routine detection of cell culture contaminants, false-negative results must be avoided more than false-positive results because of cross-reactions with bacteria that diagnose a nonmollicute but a prokaryotic infection of cell lines. Thus, when setting up PCR, one should give priority to one of the three parameters mentioned above and optimize the PCR according to the application (detection and/or identification of contaminants).

Each of the three parameters is influenced by the components of the PCR. 
Apart from template and primer design (see above), numerous other components are very important for optimizing PCR: reaction mixture [i.e., standard buffer for DNA polymerases, $\mathrm{pH}$, concentration of $\mathrm{Mg}^{2+}$, gelatin, Triton $\mathrm{X}-100$, spermidine, tetramethylammonium chloride (TMAC), dimethylsulfoxide (DMSO), glycerol, formamide, mineral oil], PCR cycles (number of steps, duration of steps, number of cycles, temperatures, ramp times), DNA polymerases (e.g., Taq, Vent, Pfu, Tth), dNTP, phase of PCR, and so forth. Alternate PCR procedures have also been used to optimize parameters. To enhance sensitivity, reverse transription-PCR (RTPCR), which consists of reverse transcription of high copy number rRNA to cDNA that is subsequently amplified, ${ }^{(22)}$ and nested PCR, which consists of a double-step PCR using internal primers to amplify the first-step PCR product $^{(16,20,23)}$ have been applied. A threeprimer PCR approach ${ }^{(32)}$ has been applied for mollicute detection to enhance specificity. ${ }^{(27)}$ Numerous reviews and books have been published on the setting up of PCR, describing general principles that can be applied to mollicute detection. $^{(31,33-39)}$

\section{Problems and Troubleshooting}

Because PCR can generate $10^{6}$ DNA copies from a template sequence, false positivity attributable to contaminating nucleic acids from a previous PCR reaction (carryover), exogenous DNA, or other cellular material is a problem in diagnostic application. To avoid PCR product (amplicons) carryover, one can take specific precautions, including (1) prealiquoting reagents, using positive displacement-dedicated pipettes or tips with cotton plugs, (2) physically separating the reaction preparation from the area of reaction product analysis, (3) using autoclaved solutions, (4) changing gloves, (5) avoiding splashes, (6) premixing reagents, adding DNA last, and (7) choosing positive and negative controls carefully. ${ }^{(40)}$ Multiple negative controls are necessary to monitor and reveal contamination. Numerous "sterilization" methods have been described. Several investigators have used nucleases, UV light, ${ }^{(41,42)}$ or $\gamma$-irradiation ${ }^{(43)}$ to inactivate contaminants in solution (or on surfaces in the case of UV), ${ }^{(44)}$ but all of these protocols have limitations, espe- cially if PCR products and contaminating DNA fragment are short in length. Others have eliminated DNA contamination by the use of photochemical (isopsoralen) and enzymatic (uracil $\mathrm{N}$-glycosylase) methods effective on PCR amplicons of $>100 \mathrm{bp} \cdot{ }^{(35,45-47)}$ Walder and co-workers prevented cross-contamination associated with PCR by the use of primers that contain a 3 '-terminal ribose residue. ${ }^{(48)}$ No sterilization protocol is likely to be $100 \%$ efficient; therefore, good laboratory practices are highly recommended.

Inhibition of the amplification reaction because of the presence of trace contaminants in samples has been described previously as a source of falsenegative results, ${ }^{(45)}$ which is another obstacle to the diagnostic use of PCR. To demonstrate that the reaction is working, one can apply multiplex amplification where an additional primer set, specific for a host gene or for a control plasmid, is added. One limitation is that the two distinct PCRs possess different efficiencies. Moreover, there is no control for the omission of the primers amplifying the target DNA. Another commonly used approach is the addition of a control template engineered by deletion or insertion that produces a shorter or longer fragment than the authentic DNA fragment using the same primer set. This approach is not a true positive control because one can omit the sample DNA being tested. Low-stringency PCR is a recent method that provides an internal control for negative results. ${ }^{(49)}$ When the primer set is used under low-stringency conditions, this technique leads to amplification of the specific DNA sequence (e.g., mollicutes), if present, and of nonspecific eukaryotic DNA found in the sample. However, at low concentrations of specific template, the problem in distinguishing the specific band from low-stringency products arises and the presence of numerous bands may complicate the readout.

\section{TRANSPORT AND STORAGE OF SAMPLES}

Diagnosis of mollicutes contaminating cell cultures is usually performed in specialized and reference laboratories. Thus, applicant laboratories have to transport their cell cultures under adequate conditions to be tested. Conventional mycoplasma detection methods require the cultivation of cells to be assayed in the diagnostic laboratory. Therefore, in the case of specific culture media (e.g., insect cell cultures), the latter must also be provided. The handling of samples could be problematic and increases the risk of bacterial and fungal contamination, because cells must be cultivated without antibiotics (see below). PCR requires only a small amount of DNA, so $1 \mathrm{ml}$ of cell cultures can serve to perform several PCR assays. van Kuppeveld et al. ${ }^{(25)}$ demonstrated that a PCR assay for the detection of mycoplasmas contaminating cell cultures can be performed on lyophilized materials. Thus, sample storage and transport to reference laboratories are simplified. In addition, cell cultures can be stored frozen for a long time without altering the amplification efficiency. Similar amplification results were obtained with fresh samples and those stored at $-20^{\circ} \mathrm{C}$ for $1 \frac{1 / 2}{2}$ years $(\mathrm{G}$. Rawadi and O. Dussurget, unpubl.). As PCR can be achieved with frozen and lyophilized materials, this offers a means for a retrospective analysis.

At present, before submitting cell cultures for mycoplasma diagnosis by conventional methods, cultivating cells in antibiotic-free culture media for at least 2 weeks is required. ${ }^{(50)}$ This measure may not be obligatory for mycoplasma diagnosis by PCR. Streptomycin, an antibiotic widely used in cell culture media, is known to bind to DNA and can be expected to interfere with Taq polymerase. However, we did not observe any differences in amplification efficiency when PCR is performed on cells cultivated with or without antibiotics (G. Rawadi, unpubl.). Nevertheless, cell cultures treated with mycoplasma removal agent, (MRA, ICN) should be passaged in culture media free of this antibiotic prior to PCR assay, as cell cultures treated with MRA have been observed to inhibit amplification (D. Roulland-Dussoix, pers. comm.).

The use of PCR-based methods for mycoplasma detection in cell cultures will facilitate sample handling considerably and reduce transport cost and inconvenience.

\section{SAMPLE PREPARATION}

Pre-PCR preparation influences subsequent PCR analysis significantly. Although PCR-based methods for myco- 
plasma detection have been described at length, few investigators deal with prePCR sample preparation. A large number of methods for the isolation of highly purified nucleic acids are suitable for use in PCR and mainly for PCR detection of mycoplasmas. However, the traditional DNA extraction methods are not adapted to the processing of a large number of samples.

Protocols described as quick and easy for the isolation of DNA suitable for use in PCR have been applied successfully for prePCR sample preparation. ${ }^{(18,19,26,27)}$ These simplified methods involve the use of proteinase $\mathrm{K}$ in the PCR buffer to release DNA from cells. Proteinase $\mathrm{K}$ has the advantage of being relatively heat stable in the mid-temperature range $\left(50-60^{\circ} \mathrm{C}\right)$ yet is thermally inactivated easily at $95^{\circ} \mathrm{C}$. The use of ionic detergent, such as SDS, in the lysis buffer must be avoided because it is not compatible with Taq polymerase at any useful level. Nonionic detergent (e.g., NP-40, Laurenth-12, Tween 20) at $0.5 \%$ is compatible with Taq polymerase activity. $^{(51)}$ Diethylpyrocarbonate (DEPC) prevents the degradation of DNA and RNA by nucleases and can be added to lysis buffer to improve the pre-PCR sample preparation protocol. However, DEPC was reported render to PCR ineffective. ${ }^{(33)}$ The pre-PCR protocols also can be improved by adding glass powder to cell lysates, as described by Yamada et al. ${ }^{(52)}$ Glass powder specifically binds nucleic acid molecules and can be separated from the lysate by centrifugation. DNA or RNA can then be recovered by heating at $55^{\circ} \mathrm{C}$.

The mere boiling of samples was also used to release DNA from mollicutes prior to PCR amplification. ${ }^{(21)}$ However, it has been shown that prolonged heating of DNA reduces the efficiency of its amplification. Therefore, we believe that the proteinase $\mathrm{K}$ protocol is more applicable.

A point that should be considered in the pre-PCR sample preparation step is that extreme care must be taken to avoid false-positive results. False positives can result from sample-to-sample contamination. A more serious source of contamination is the carryover of DNA from previous amplifications of the same target. Thus, procedures to minimize the risk of false-positives results should be followed strictly. ${ }^{(53)}$ In addition, reagents used for sample preparation can be sterilized by UV irradiation (see Problems and Troubleshooting above). ${ }^{(42,54)}$

\section{MYCOPLASMA DETECTION AND IDENTIFICATION BY PCR-BASED METHODS}

\section{Mycoplasma detection}

Blanchard et al. ${ }^{(26)}$ showed that it was possible to utilize $16 \mathrm{~S}$ rRNA genes to detect mollicutes by PCR amplification. The method described by these investigators is not appropriate for the detection of mollicutes contaminating cell cultures because strains currently isolated from cell cultures are not amplified (e.g., M. hyorhinis). Thus, they focused their efforts on the development of PCR protocols used specifically for mycoplasma detection in cell cultures.

Several PCR methods based on $16 \mathrm{~S}$ rDNA amplification have been described. These methods involve one- or two-step nested PCRs. Spaepen et al. ${ }^{(20)}$ and Hopert et al. ${ }^{(16)}$ described distinct nested PCR protocols. The method developed by Spaepen et al. consists of the amplification of bacterial 16S rDNA in the first round of PCR. Nested PCR was then performed with mollicute-specific primers to detect this contamination. $A$. laidlawii, a common contaminant of cell cultures, was not amplified correctly by this method. The detection of bacterial contamination of cell cultures is not problematic in that it can be spotted visually. However, culture media are usually supplemented with antibiotics; thus, they may be contaminated with DNA from eradicated or dormant bacteria. Given the high sensitivity of PCR, such an approach may lead to a false-positive diagnosis. Moreover, it is well documented that the use of nested PCR increases the risk of nonspecific amplification. The second nested PCR protocol was shown to be apparently mollicutespecific in both PCR steps. ${ }^{(16)}$ Similar results (positive or negative diagnosis) were obtained in first- and second-round PCR. Nevertheless, the second PCR run was shown to increase the sensitivity of detection in a serial dilution assay of infected samples. Southern blotting of PCR products and hybridization with a specific radiolabeled internal probe is more suitable to improve the sensitivity of mycoplasma diagnosis. In this way, such sensitivity could be increased up to 10 fold. ${ }^{(18,22,27)}$ Furthermore, in cases where laboratories are not accustomed to the handling of radioactive products, Southern blot analysis can be performed with biotinylated probes.

The 16S-23S spacer region in rRNA operons has also been used as an amplification target for mycoplasma detection. ${ }^{(29)}$ This nested PCR approach has been shown to be suitable for mycoplasma detection in cell cultures. ${ }^{(23,24)}$

The reported one-step PCR-based methods involve primer sets that anneal to almost all mollicutes. As discussed previously, Acholeplasma species is problematic for mollicute primer design. To achieve reliable detection of mycoplasma in cell cultures, this species should be amplified. Two primer sets for PCR, one for the specific detection of $A C$ holeplasma and a second for the detection of the other mollicutes species, have been described. ${ }^{(21)}$ However, suitable primers have been shown to allow $A c$ holeplasma as well as Mycoplasma species amplification in the same PCR run. In an attempt to develop protocols to amplify mollicutes-contaminating cell cultures, including Acholeplasma, care should be taken to avoid cross-reactivity with other bacterial DNA. Although the method described by Deng et al. ${ }^{(55)}$ amplifies several mollicute species (including Acholeplasma), it also surprisingly amplifies DNA from plant tissue. Moreover, the latter techniques have been shown to cross-react with Clostridia. ${ }^{(21,55)}$ Protocols for specific amplification of mollicutes commonly found in cell cultures (including Acholeplasma) and additional Mycoplasma species rarely isolated (e.g., $M$. bovis, $M$. pirum, and $M$. hominis) have been described. ${ }^{(18,19,22)}$ van Kuppeveld et al. $^{(22)}$ reported primers that were capable of amplifing members of Ureaplasma and Spiroplasma species as well. Using similar protocols, we did not observe cross-reactivity with any of a series of Gram-negative or Gram-positive bacteria, including Clostridia, even at $10^{6}$ bacteria/ml. ${ }^{(18)}$ These methods ${ }^{(18,19,25)}$ were validated by diagnosis of a large number of cell cultures and were capable of detecting all of the contaminating mollicutes when compared to conventional methods.

\section{Mycoplasma Identification}

Identification of mollicute species contaminating cell cultures can also be achieved by PCR amplification using 
species-specific primers. ${ }^{(18,19,22,26)}$ Samples that appear to be infected with mollicutes, using genus-specific PCR amplification, can be submitted to a species-specific PCR to identify the contaminant. The identification may be performed by combining a genus-specific primer and a species-specific primer. Therefore, PCR amplifications should be conducted on each contaminated sample using available species-specific primers.

Typical contaminating species (i.e., $M$. hyorhinis, $M$. orale, $M$. fermentans, $M$. salivarium, $M$. arginini, and $A$. laidlawii) cause $98 \%$ of infection. This should be considered when performing PCR to identify these cultures, in that speciesspecific primers of these contaminants systematically have to be used first. PCR identification results of contaminated mollicutes displayed this same prevalence (Table 3$)$. $(18,19,25)$ In rare cases, when mycoplasma contamination is detected by mollicute-specific PCR methods, species-specific PCR failed to identify the contaminating mycoplasmas $(2 \%$; see Table 3$) .^{(18,19)}$ However, in these cases, employing species-specific primers for mycoplasma rarely found in cell cultures (e.g., M. pirum, M. bovis, and $M$. hominis) did not resolve the identification. van Kuppeveld et al. ${ }^{(25)}$ detected only $1 \mathrm{M}$. pirum isolate among 67 contaminated cell cultures (Table 3 ).

Amplicons from mollicute genus-specific PCR amplification can be cloned easily using the TA cloning system, ${ }^{(56)}$ and the variable $16 \mathrm{~S}$ rDNA region can also be sequenced. Sequence analysis by comparing published 16S rDNA genes allows the identification of the contaminated species. The standard sequencing technique is time consuming; therefore, semiautomated systems using biotinylated primers and solid-phase sequencing of PCR products have been described $^{(57)}$ and shown to be useful for mycoplasmic $16 \mathrm{~S}$ rDNA sequencing. ${ }^{(58)}$ The association of mollicute genus-specific PCR amplification and sequencing should prove to be a valuable technology for discriminating all mycoplasma contaminations.

Analysis of restriction fragment length polymorphism (RFLP) of the $16 \mathrm{~S}$ rDNA amplified segments was used to identify mollicute species. ${ }^{(54)}$ Restriction enzyme digestion time can be reduced considerably, up to minutes, by utilizing a microwave oven. ${ }^{(59)}$ RFLP analysis of the $16 \mathrm{~S}-23 \mathrm{~S}$ intergenic amplified fragment was also developed for species identification. ${ }^{(23,24)}$. However, RFLP profiles are established mainly from type strains, and variation of these profiles may occur between strains within the same species. Thus, interpretation of RFLP results should be confirmed by other identification methods.

\section{PCR Controls}

All reports are consistent with the fact that PCR is the most sensitive, specific, and reliable method for mycoplasma detection. This technique could be subjected to automation, thus allowing the analysis of a large number of samples under the same conditions, which en-

TABLE 3 Prevalence of Mycoplasma-contaminated Cell Cultures Determined by PCR-based Diagnosis

\begin{tabular}{|c|c|c|c|}
\hline & Ref. 18 & Ref. 19 & Ref. 43 \\
\hline $\begin{array}{l}\text { Total number of cell cultures tested } \\
\text { Percentage of contaminated }\end{array}$ & $\overline{114}$ & $\overline{372}$ & $\overline{104}$ \\
\hline cell cultures & 31 & 23 & 64 \\
\hline \multicolumn{4}{|l|}{ Species identification } \\
\hline M. arginini & $57 \%$ & $11.6 \%$ & $32.8 \%$ \\
\hline M. hyorhinis & $17 \%$ & $51.2 \%$ & $37.3 \%$ \\
\hline M. fermentans & 0 & $11.6 \%$ & $7 \%$ \\
\hline M. orale & $23 \%$ & $15.1 \%$ & $17.9 \%$ \\
\hline A. laidlawii & 0 & $1.2 \%$ & $2.9 \%$ \\
\hline M. pirum & 0 & 0 & $1.5 \%$ \\
\hline Mixed contamination $^{a}$ & 0 & $7 \%$ & 0 \\
\hline Unidentified species ${ }^{b}$ & $3 \%$ & $2 \%$ & 0 \\
\hline
\end{tabular}

${ }^{a}$ Cell cultures contaminated by more than one mycoplasma species.

${ }^{b}$ Mycoplasma contamination detected by mollicute-specific PCR, but not identified by speciesspecific PCR.

sure repeatability and reproducibility. However, two significant problems that have arisen from the wide use of PCR technology should be considered: (1) the presence of polymerase inhibitors in some cell cultures, and (2) DNA carryover contamination. This leads to falsenegative or false-positive diagnosis, respectively. Since the inception of PCR, users pointed out the occurrence of carryover contamination owing to the abundance of DNA generated by PCR amplification. Cautions that should be taken to prevent this problem are well documented and have been discussed above.

The real nature of the polymerase inhibitors found in some cell cultures is not well known. This problem has been reported in mycoplasma PCR-based assay. ${ }^{(19)}$ The presence of such inhibitors in tested samples could be detected by using multiplex amplification. A low stringency (LS)-PCR-derived method has been developed in our laboratory that involves decreasing the primer annealing temperature by $3^{\circ} \mathrm{C}$ (i.e., from $55^{\circ} \mathrm{C}$ to $52^{\circ} \mathrm{C}$ ). In case of contaminated cell cultures, primer pairs match specifically to mycoplasmic $16 \mathrm{~S}$ rDNA yielding the expected size fragment exclusively, whereas in mycoplasma-free samples, mismatched priming throughout eukaryotic DNA results in nonspecific amplification (Fig. 2). This was tested in $>100$ cell cultures and was found to provide a reliable and simple method to verify negative diagnosis.

\section{COMPARISON OF PCR WITH CONVENTIONAL METHODS FOR THE DETECTION OF MYCOPLASMAS}

The first isolation of mycoplasma from a contaminated cell culture goes back to $1956 .{ }^{(60)}$ The development of in vitro cell culture as a tool for basic research highlighted the problem of contamination with mollicutes. In the years that followed, numerous direct or indirect methods for the detection of mycoplasmas in cell cultures have been developed.

Direct methods consist primarily of microbiological cultivation procedures with specific media. Although this method is considered to be the most sensitive and specific, cultivation for $\geqslant 10$ 14 days is necessary to obtain results. Moreover, some Mycoplasma species 

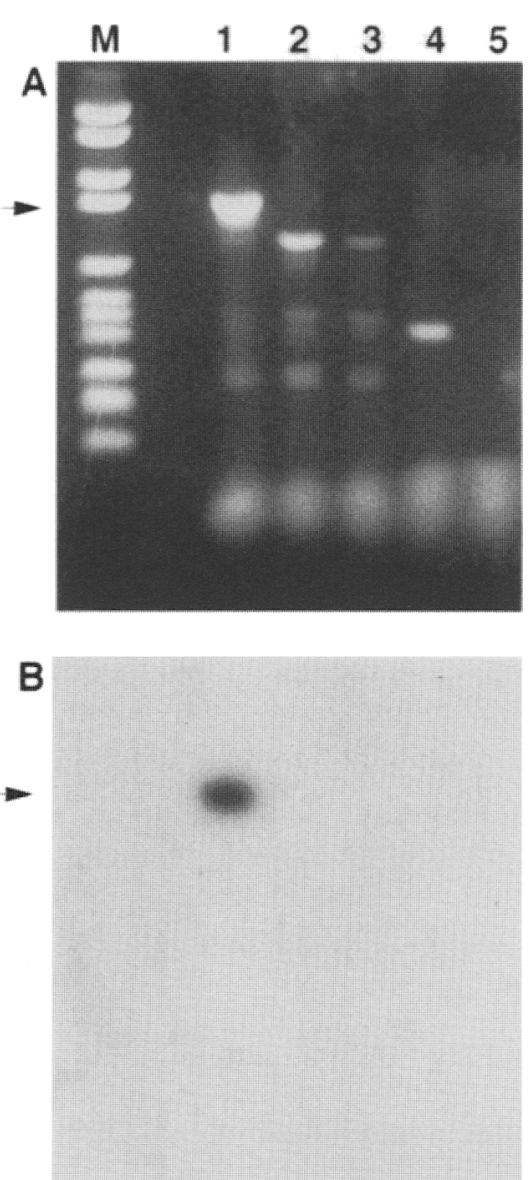

FIGURE 2 Mycoplasma detection in cell culture by LS-PCR-derived technique. Cell cultures were diagnosed for mycoplasma contamination as described previously, ${ }^{(18)}$ except that annealing temperature was shifted from $55^{\circ} \mathrm{C}$ to $52^{\circ} \mathrm{C}$. $(A)$ Ten microliters of amplified product was analyzed by $1.5 \%$ agarose gel electrophoresis. Amplified products were detected under UV fluorescence after ethidium bromide staining. (Lane 1) Rat basophilic leukemia (RBL)-contaminated cell line; (lane 2) RBL mycoplasma-free cell line; (lane 3) Chinese hamster ovary $(\mathrm{CHO})$ mycoplasma-free cell line; (lane 4) U937 mycoplasma-free cell line; (lane 5) no DNA; (lane M) molecular weight marker (pBR328-BglI, Hinfl). Only infected cell cultures yielded a specific band at the expected size (1000 bp, arrow), whereas in mycoplasma-free cell cultures nonspecific fragments were generated. $(B)$ The specificity of the amplification was tested by Southern blot analysis of the same samples with a radiolabeled internal probe as described previously. ${ }^{(18)}$

(i.e., M. hyorhinis) cannot be cultivated and consequently remain undetected by these methods. Until now, these procedures are regarded as the standard for the validation of new techniques. Indirect methods involve microscopy observation (e.g., fluorochrome DNA staining, electron microscopy), ELISA, biochemical assays [e.g., adenosine phosphorylase (AdoP) activity], and molecular biological tests (e.g., DNA-DNA hybridization and PCR-based assays described in this review). Some methods based on the modulation of thymidine incorporation by proliferating cells have been described for the detection of mycoplasma infection. ${ }^{(61,62)}$ These techniques are rarely used in diagnostic laboratories because the proliferation of cells may be stimulated or inhibited by several components that might be present in the supernatants of cell cultures. Thus, the observed effects are not necessarily correlated to mycoplasma infection.

DNA fluorochrome staining is used widely for mycoplasma detection in cell cultures. ${ }^{(63)}$ This technique, as well as the AdoP activity-based assay, requires the use of a permanent indicator cell line free of mollicutes (e.g., Swiss albino mouse embryo fibroblast-3T6 cell line, Vero cell line). Indicator cells are cultured with 100 - to $200-\mu l$ of the specimens to be tested under adequate conditions, and stained with fluorochrome (e.g., Hoechst 33258). Mollicutes are detected under epifluorescence microscopy as extranuclear fluorescent bodies.

AdoP activity assay is based on the observation of cell toxicity induced by the degradation of 6-methylpurine deoxyriboside (6-MPDR) to 6-methylpurine ribose. ${ }^{(64)}$ Samples $(100-200 \mu \mathrm{l})$ are added with 6-MPDR to indicator cell culture, and incubated under adequate conditions for 48-72 hr; cells are then observed using classic microscopy for cell toxicity. Both of these methods give false-positive or false-negative results. ${ }^{(3,18)}$

Electron microscopy (i.e., scanning and transmission electron microscopy), a traditional technology, needs specific equipment and a trained staff. Although these techniques have been applied for the detection of mollicutes, ${ }^{(65)}$ they can hardly be used as routine tests. Thus, their use is focused on mycoplasma basic research.

ELISAs are easy to perform but have been also shown to produce false-negative results. ${ }^{(16,21)}$ This is because of part to the relatively weak sensitivity of this technique. Moreover, commercially available ELISA detection kits mainly address certain mollicute species (i.e., $M$. hyorhinis, $M$. orale, $M$. arginini, and $A$. laidlawii). The ELISA technique is more appropriate for mycoplasma identification than for mycoplasma detection.

This short inventory of conventional and commonly used assays for the detection of mycoplasma infection in cell cultures shows that there is no standard method. At least two or three techniques should be conducted on the same sample to obtain a reliable diagnosis. Molecular biological tests, that is, DNA-DNA hybridization and PCR amplification, surpass all of these conventional methods in reliability and sensitivity. DNADNA hybridization is based on either $16 \mathrm{~S}$ rRNA or $23 \mathrm{~S}$ rRNA gene hybridization. ${ }^{(66,67)}$ These methods are quite rapid but have been shown to cross-react with gram-positive bacteria, especially the H900 probe, yielding nonspecific hybridization. ${ }^{(66)}$ The detection limit of the hybridization assay is $10^{3}-10^{4}$ organisms; thus, it is not suitable for monitoring eradication of mycoplasma contamination or for the detection of the onset of contamination. Moreover, this technique requires the use of a radioactive element that may be problematic for safety and regulatory reasons.

In our hands, no false-negative or false-positive results were observed using PCR-based methods. Similar observations were made by the vast majority of reports dealing with the PCR detection of mycoplasmas when compared with classic methods, including DNA-DNA hybridization. ${ }^{(16,18,19,21,22)}$ A PCR assay is more specific than other assays when the primers used are chosen purposefully. This assay does not require the cultivation of mollicutes; thus, it can overcome the problem of uncultivatable strains. The sensitivity of PCR-based methods was shown to be as little as a single organism per milliliter ${ }^{(22)}$ or 1 organism $/ 10^{3}$ cells in mock-infected cultures. ${ }^{(18)}$ The sensitivity of the PCR diagnosis could be increased 10-fold by analyzing the amplified materials by Southern blot. Usually, cells are heavily infected at the level of $\sim 100$ organisms/ $\mathrm{ml}$ of cell culture. ${ }^{(13)}$ Nevertheless, the sensitivity of the PCR assay also allows the detection of early contamination and the monitoring of MRA treatment of infected cultures. In addition, this high sensitivity provides a means for detecting mollicutes in commercial animal sera, a serious source of contamination. ${ }^{(27)}$ Altogether, PCR is superior to 
most classical methods developed for the detection of mycoplasmas in cell cultures and should prove to be the technique of the future.

\section{CONCLUSION}

Mollicute-infected cultures are themselves the major source of infection of cell cultures. Guidelines have been published that form the basis of an efficient quality control program for the prevention of mollicute infection of cell cultures, ${ }^{(13)}$ including acquisition of cell lines from reputable cell collections, reception in the laboratory and quarantine until sterility is attained and mollicute tests have been performed (as for media components, especially serum), periodic mollicute detection assays (at least quarterly), preservation of the mollicute-free cell culture in liquid nitrogen, use of antibiotic-free media to prevent undetected infections, especially in stock cultures, and disinfection of working surfaces. Attempts to eliminate mollicutes from contaminated cells should be considered only as a last resort. It is often better to destroy the infected culture by autoclaving and replacing it with a mollicute-free stock culture. However, when the infected cell culture is irreplaceable, the following procedures can be used to eliminate mollicutes: ${ }^{(7,10,13)}$ treatment with anti-mollicute antisera, passage through mice, exposure to murine macrophages, treatment of cells with 5-bromouracil or merocyanine 540 and Hoechst 33258 followed by exposure to light, ${ }^{68,69)}$ prolonged heat treatment, and selective killing with antibiotics [tylosin, spectinomycin, tiamulin, minocyclin, gentamycin, neomycin, kanamycin, novobiocin, thialine, quinolones, MRA (ICN), BM-Cyclin (Boerhinger Mannhiem), etc.], or mycoplasmacidal drugs. Antibiotic treatment is the most common method, but it is time consuming and its efficiency is variable depending on the resistance of the cell line to toxicity and on the sensitivity of the containment to antibiotics. It has been shown that some mollicutes possess intracellular parasitism properties (e.g., $M$. fermentans) and are therefore able to resist antibiotic treatments. None of these methods can be regarded as standard and no irrefutable assay has been developed yet.

Numerous comparative studies of methods for detecting mollicute con- tamination in cell cultures have been published recently. ${ }^{(16-19,21,49)}$ From individual studies reviewed, it can be concluded that PCR provides a rapid, sensitive, and reliable method for detecting and identifying mollicutes in cell cultures. Although there is no standard for the detection of mollicute contamination of cell cultures, projects to establish standard methods and protocols are currently in development. Arai and coworkers have already presented a 3-year study for evaluating methods, especially PCR, to detect mollicute contamination in industrial biological materials. ${ }^{(7)}$ Standardization in PCR procedures is needed to ensure reliable results and to avoid variation in results among different laboratories, which is crucial when PCR is used as a diagnostic tool. ${ }^{(70)}$ The International Research Program on Comparative Mycoplasmology (IRPCM) is also currently performing an international multicenter collaborative trial to evaluate PCR-based diagnosis of mollicute infection of cell cultures. This trial will provide useful data to assess the reliability of PCR and to develop PCR standards, leading to large-scale validation of this powerful technology applied to the diagnosis of cell culture infection.

\section{ACKNOWLEDGMENTS}

We thank Dr. R. Harasawa and Dr. D. Roulland-Dussoix for their critical reading of this manuscript. We acknowledge Dr. D. Lecaque for helpful electron microscopy assistance.

\section{REFERENCES}

1. Tully, J.G. 1992. Mollicutes. In Encyclopedia of microbiology (ed. J. Lederberg), vol. 3, pp. 181-191. Academic Press, New York.

2. Hay, R.J., M.L. Macy, and T.R. Chen. 1989. Mycoplasma infection of cultured cells. Nature 339: 487-488.

3. Bölske, G. 1988. Survey of mycoplasma infections in cell cultures and a comparison of detection methods. Zentralbl. Bakteriol. Mikrobiol. Hyg. 269: 331-340.

4. Pawar, V., J. Luczak, M.S. Cox, J. Dubose, and J.W. Harbell. 1994. Trends in the incidence and distribution of mycoplasma contamination detected in cell lines and their products. Int. Organ. Mycoplasmol. Lett. 3: 77 .

5. Polak-Vogelzang, A.A., J. Brugman, and R. Reijgers. 1987. Comparison of two methods for detection of Mollicutes (Mycoplasmatales and Acholeplasmatales) in cell cultures in the Netherlands. Antonie Leeuwenhoek. J. Microbiol. 53: 107-118.

6. Uphoff, C.C., S. Brauer, D. Grunicke, S.M. Gignac, R.A.F. Mac Leod, H. Quentmeier, K. Steube, M. Tümmler, M. Voges, B. Wagner, and H.G. Drexler. 1992. Sensitivity and specificity of five different mycoplasma detection assays. Leukemia 6: 335-341.

7. Arai, S., R. Harasawa, T. Ohno, M. Takeuchi, K. Hikizi, N. Kobayashi, I. Lee, K. Kato, H. Takahashi, I. Okamoto, and T. Furudera. 1994. Comparative studies to detect mycoplasma contamination in bioindustrial materials, for validating standard method. Int. Organ. Mycoplasmol. Lett. 3: 48-49.

8. McGarrity, G.J., H. Kotani, and D. Carson. 1986. Comparative studies to determine the efficiency of 6 methylpurine deoxyriboside to detect cell culture mycoplasmas. In Vitro Cell. Dev. Biol. 22: 301-304.

9. McGarrity, G.J., H. Kotani, and G.H. Butler. 1992. Mycoplasmas and tissue culture cells. In Mycoplasmas. Molecular biology and pathogenesis (ed. J. Maniloff, R.N. McElhaney, L.R. Finch, and J.B. Baseman), pp. 445-454. American Society for Microbiology, Washington, D.C.

10. Barile, M.F. and S. Rottem. 1993. Mycoplasmas in cell cultures. In Rapid diagnosis of mycoplasmas (ed. I. Kahane, and A. Adoni), pp. 155-193. Plenum Press, New York.

11. Somerson, N.L. and B.C. Cole. 1979. The mycoplasma flora of human and nonhuman primates. In The mycoplasmas (ed. J. G. Tully, and R. F. Whitcomb), vol. 2, pp. 191-216. Academic Press, New York.

12. Gabridge, M.G. and D. J.Lundin. 1989. Cell culture user's guide to mycoplasma detection and control. Bionique Laboratories, New York.

13. McGarrity, G.J. and H. Kotani. 1985. Cell culture mycoplasmas. In The mycoplasmas (ed. S. Razin, and M. Barile), vol. 4, pp. 353-390. Academic Press, New York.

14. Saiki, R.K., D.H. Gelfand, S. Stoffel, S.J. Scharf, R. Higuchi, G.T. Horn, K.B. Mullis, and H.A. Erlich. 1988. Primer-directed enzymatic amplification of DNA with thermostable DNA polymerase. Science. 239: 487-491.

15. Weisburg, W.G., J.G. Tully, D.L. Rose, J.P. Petzel, H. Oyaizu, D. Yang, L. Mandelco, J. Sechrest, T.G. Lawrence, J. van Etten, J. Maniloff, and C.R. Woese. 1989. A phylogenetic analysis of the mycoplasma: Basis for their classification. J. Bacteriol. 171: 6455-6467.

16. Hopert, A., C.C. Uphoff, M. Wirth, H Hauser, and H.G. Drexler. 1993. Specificity and sensitivity of polymerase chain reaction (PCR) in comparison with other methods for the detection of mycoplasmas contamination in cell lines. J. Immunol. Methods 164: 91-100. 
17. Penn, L., K. Leung, C. McDowell, and P. Quinn. 1994. Evaluation of the polymerase chain reaction for the detection of mycoplasma contamination of tissue culture cells. Int. Organ. Mycoplasmol. Lett. 3: 778-79.

18. Rawadi, G., D. Lecaque, D. Pirot, and S. Roman-Roman, 1993. Detection and identification of mycoplasma contamination in cell cultures by polymerase chain reaction. Methods Mol. Cell. Biol. 4: 147156.

19. Roulland-Dussoix, D., A. Henry, and B. Lemercier. 1994. Detection of mycoplasmas in cell cultures by PCR: A one year study. J. Microbiol. Methods 19: 127-134.

20. Spaepen, M., A.F. Angulo, P. Marynen, and J.P. Cassiman. 1992. Detection of bacterial and mycoplasmal contamination in cell cultures by polymerase chain reaction. FEMS Microbiol. Lett. 99: 89-94.

21. Teyssou, R., F. Poutiers, C. Saillard, O. Grau, F. Laigret, J.M. Bové, and C. Bébéar. 1993. Detection of mollicute contamination in cell cultures by $16 \mathrm{~S}$ rDNA amplification. Mol. Cell. Probes 7: 209-216.

22. van Kuppeveld, F.J.M., J.T.M. van der Logt, A.F. Angulo, M.J. van Zoest, W.G.V. Quint, H.G.M. Niesters, J.M.D. Galama, and W.J.G. Melchers. 1992. Genus- and species-specific identification of mycoplasmas by $16 \mathrm{~S}$ rDNA amplification. Appl. Environ. Microbiol. 58: 2606-2615.

23. Harasawa, R., H. Mizusawa, K. Nozawa, T. Nakagawa, K. Asada, and I. Kato. 1993. Detection and tentative identification of dominant mycoplasma species in cell cultures by restriction analysis of the $16 \mathrm{~S}-23 \mathrm{~S}$ rRNA intergenic spacer regions. Res. Microbiol. 144: 489-493.

24. Harasawa, R., H. Mizusawa, K. Nozawa, T. Nakagawa, K. Asada, and I. Kato. 1994. Detection and identification of dominant mycoplasma species in cell cultures by restriction analysis of the 16S-23S rRNA intergenic spacer regions. Int. Organ. Mycoplasmol. Lett. 3: 68-69.

25. van Kuppeveld, F.J.M., K.E. Johansson, J.M.D. Galama, J. Kissing, G. Bölske, J.T.M. van der Logt, and W.J.G. Melchers. 1994. Detection of mycoplasma contamination in cell cultures by a mycoplasma group-specific PCR. Appl. Environ. Microbiol. 60: 149-152.

26. Blanchard, A., M. Gautier, and V. Mayau. 1990. Detection and identification of mycoplasmas by amplification of rDNA. FEMS Microbiol. Lett. 81: 37-42.

27. Dussurget, O. and D. Roulland-Dussoix. 1994. Rapid, sensitive PCR-based detection of mycoplasmas in simulated samples of animal sera. Appl. Environ. Microbiol. 60: 953-959.

28. McKenzie, D. 1992. PCR-mediated detection of mycoplasma. Strategies 5: 65 .

29. Uemori, T., K. Asada, I. Kato, and R. Harasawa. 1992. Amplification of the 16S-
23S spacer region in rRNA operons of mycoplasmas by the polymerase chain reaction. System. Appl. Microbiol. 15: 181186.

30. He, Q., M. Marjamäki, H. Soini, J. Mertsola, and M. K. Viljanen. 1994. Primers are decisive for sensitivity of PCR. BioTechniques 17: 82-87.

31. Cha, R.S. and W.G. Thilly. 1993. Specificity, efficiency, and fidelity of PCR. PCR Methods Applic. 3: S18-S29.

32. Kai, M., S. Kamiya, S. Sawamura, T. Yamamoto, and A. Ozawa. 1991. Simplified method for confirmation of PCR products. Nucleic Acids Res. 16: 4562.

33. Coen, D.M. 1992. The polymerase chain reaction. In: Current protocols in molecular biology (ed. F.M. Ausubel, R. Brent, R.E. Kingston, D.D. Moore, J.G. Seidman, J.A. Smith and K. Strhul), vol. 2, pp. 15.0.315.1.7. Greene Publishing Associates/ Wiley \& Son, New York.

34. Dieffenbach, C.W., T.M.J. Lowe, and G.S. Dveksler. 1993. General concepts for PCR primer design. PCR Methods Applic. 3: S30-S37.

35. Erlich, H.A., D. Gelfand, and J.J. Sninsky. 1991. Recent advances in the polymerase chain reaction. Science 252: 1643-1651.

36. Innis, M.A., D.H. Gelfand, J.J. Sninsky, and T.J. White. 1990. PCR protocols. Academic Press, San Diego, CA.

37. Oste, C. 1988. Polymerase chain reaction. BioTechniques 6: 162-167.

38. White, B.A. 1993. PCR protocols. Current methods and applications. In Methods in molecular biology, vol.15. Humana Press, Totowa, NJ.

39. Wolcott, M.J. 1992. Advances in nucleic acid-based detection methods. Clin. Microbiol. Rev. 5: 370-386.

40. Kwok, S. and R. Higuchi. 1989. Avoiding false positives with PCR. Nature 339: 237-238.

41. Ou, C.Y., J.L. Moore, and G. Schochetman. 1991. Use of UV irradiation to reduce false positivity in polymerase chain reaction. BioTechniques 10: 442-445.

42. Sarkar, G. and S. Sommer. 1990. Shedding light on PCR contamination. Nature 343: 27 .

43. Deragon, J.M., D. Sinnett, G. Mitchell, M. Potier, and D. Labuda. 1990. Use of $\gamma$ irradiation to eliminate DNA contamination for PCR. Nucleic Acids Res. 18: 6149.

44. Cone, R.W. and M.R. Fairfax. 1993. Protocol for ultraviolet irradiation of surfaces to reduce PCR contamination. PCR Methods Applic. 3: S15-S17.

45. Clewley, J.P. 1989. The polymerase chain reaction, a review of the practical limitations for human immunodeficiencies virus diagnosis. J. Virol. Methods 25: 179188.

46. Espy, M.J., T.F. Smith, and D.H. Persing. 1993. Dependence of polymerase chain reaction product inactivation protocols on amplicon length and sequence composition. J. Clin. Microbiol. 31: 23612365.

47. Persing, D.H. 1991. Polymerase chain reaction: Trenches to benches. J. Clin. Microbiol. 29: 1281-1295.

48. Walder, R.Y., J.R. Hayes, and J.A. Walder. 1993. Use of PCR primers containing a 3'terminal ribose residue to prevent crosscontamination of amplified sequences. Nucleic Acids Res. 21: 4339-4343.

49. Damas de Caballero, O.L.S., E.D. Neto, M.C. Koury, A.J. Romanha, and A.J.G. Simpson. 1994. Low-stringency PCR provides an internal control for negative results in PCR-based diagnosis. PCR Methods Applic. 3: 305-307.

50. McGarrity, G.J., J. Sarama, and V. Vanaman. 1979. Factors influencing microbiological detection of mycoplasmas in cell culture. In vitro 15: 73-81.

51. Gelfand, H.H. 1989. Taq polymerase. In PCR technology: principles and applications for DNA amplification (ed. H.A. Eldrich), pp. 17-22. Stockton Press, New York.

52. Yamada, O., T. Matsumoto, M. Nakashima, S. Hagari, T. Kamahora, H. Ueyama, Y. Kishi, H. Uemura, and T. Kurimura. 1990. A new method for extracting DNA or RNA for PCR. J. Virol. Methods 27: 203210.

53. Kwok, S. 1990 . Procedures to minimize PCR-product carry-over. In: PCR protocols: A guide to methods and applications (ed. M.A. Innis, D.H. Gelfand, J.J. Sninsky, and T.J. White), pp. 142-145. Academic Press, San Diego, CA.

54. Sarkar, G. and S. Sommer. 1990. More light on PCR contamination. Nature 347: $340-341$

55. Deng, S., C. Hiruki, J.A. Robertson, and G.W. Stemke. 1992. Detection by PCR and differentiation by restriction fragment length polymorphism of Acholeplasma, Spiroplasma, Mycoplasma and Ureaplasma. PCR Methods Applic. 1: 202-204.

56. Kovalic, D., J-H. Kwok, and B. Weisblum. 1991. General method for direct cloning of DNA fragments generated by PCR. Nucleic Acids Res. 19: 4650.

57. Wahlberg, J., A. Holmberg, S. Berg, T. Hultman, and M. Uhlén. 1992. Automated magnetic preparation of DNA templates for solid phase sequencing. Electrophoresis 13: 547-551.

58. Petterson, B., K.E. Johansson, and M. Uhlén. 1993. Direct automated solid phase sequencing in an in vitro amplified segment of $16 \mathrm{~S}$ rDNA from bacteria. In Proceedings of the Sixth European Congress on Biotechnology (ed. L. Alberghina, L. Frontali, and P. Sensi), pp. 359-362. Elsevier, Amsterdam, The Netherlands.

59. Jhingan, A.K. 1992. Microwave restriction enzyme digestion of DNA. Methods Mol. Cell Biol. 3: 270-274.

60. Robinson, L.B., R.H. Wichelhausen, and 
B. Roizman. 1956. Contamination of human cell cultures by pleuropneumonialike organisms. Science. 124: 1147-1148.

61. Alzani, R., R. Rossi, E. Cozzi, D. Trizio, and F. Marcucci. 1992. Detection of mycoplasma contamination through modulation (stimulation or inhibition) of thymidine incorporation by stimulated mouse spleen cells. J. Immunol. Methods 152: 35-42.

62. Sinigaglia, K., F. Scheidegger, D. Talmadge, and G. Garotte. 1985. A sensitive and quantitative microassay for the detection of mycoplasma contamination: Inhibition of IL-2 dependent cell line prolifiration. J. Immunol. Methods 76: 85-92.

63. Chen, T.R. 1978. In situ detection of mycoplasma contamination in cell cultures by fluorescent Hoechst 33258 stain. Exp. Cell. Res. 104: 255-262.

64. McGarrity, G.J. and D.A. Carson. 1982. Adenosine phosphorylase-mediated nucleoside toxicity. Exp. Cell. Res. 139: 199205.

65. Phillips, D.M. 1978. Detection of mycoplasma contamination of cell cultures by electron microscopy. In Mycoplasma infection of cell cultures (ed. G.J. McGarrity, D.G. Murphy, and W.W. Nichols), pp. 105-118. Plenum Press, New York.

66. Johanssen, K.E., I. Johanssen, and U.B. Göbel, 1990. Evaluation of different hybridization procedures for the detection of mycoplasma contamination in cell cultures. Mol. Cell. Probes 4: 33-42.

67. Johanssen, K.E. 1993. Detection and identification of mycoplasma with diagnostic DNA probes complementary to ribosomal RNA. In Rapid diagnosis of mycoplasma (ed. I. Kahane and A. Adoni), pp. 139-154. Plenum Press, New York.

68. Marcus, M., U. Lavi, I. Nattenberg, S. Rottem, and O. Markovitz. 1980. Selective killing of mycoplasmas from contaminated mammalian cells in cell culture. Nature 285: 659

69. Tarshis, M., A. Katzenel, and S. Rottem. 1993. Use of Merocyanine 540 and Hoechst 33258 for the selective killing of contaminating mycoplasmas in cell cultures. J. Immunol. Methods 168: 245-252.

70. Bockstahler, L.E. 1994. Overview of international PCR standardization efforts. $P C R$ Methods Applic. 3: 236-267. 


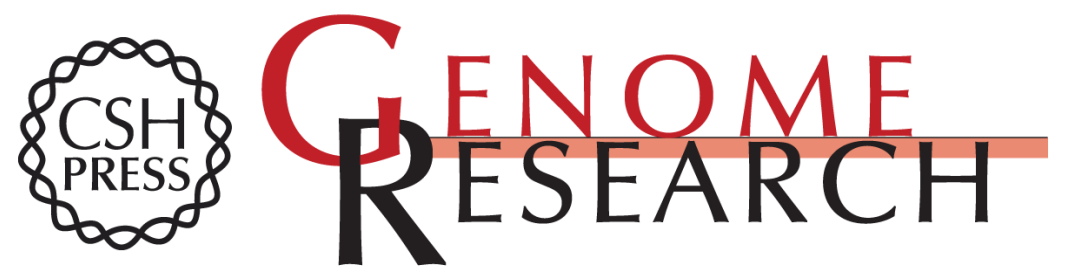

\section{Advances in PCR-based detection of mycoplasmas contaminating cell cultures.}

G Rawadi and O Dussurget

Genome Res. 1995 4: 199-208

References This article cites 56 articles, 10 of which can be accessed free at: http://genome.cshlp.org/content/4/4/199.full.html\#ref-list-1

\section{License}

Email Alerting

Receive free email alerts when new articles cite this article - sign up in the box at the Service top right corner of the article or click here.

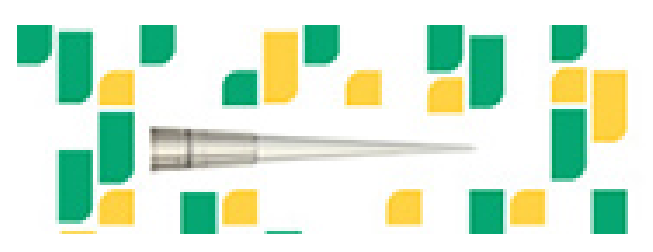

To subscribe to Genome Research go to: https://genome.cshlp.org/subscriptions 